\title{
Resilience in computer networks and personal well-being: Computer engineering at the service of digital life
}

\author{
Resiliência em redes de computadores e bem-estar pessoal: Engenharia da \\ Computação à serviço da vida digital
}

\author{
Ana Carolina Carius ${ }^{1 *}$, Claro Ribeiro Pires ${ }^{1}$, Vanessa Moreira Wendling ${ }^{1}$, Eduardo Campos \\ Papa $^{2}$
}

\begin{abstract}
From personal computers with internet access from a fixed location to today's smartphones with personalized internet access anywhere, behavioral changes resulting from technological advances accumulate daily. With the COVID-19 pandemic and the expansion of the home office, home education, telemedicine, among countless other activities developed remotely because of social distancing, the internet has become a unique space in activities in which it did not play such a role before. Given this emergency and historical scenario, the present work aims to assess the social impact of a resilience solution for computer networks, based on the continuous need for internet connection in present society. The device in question maintains the internet connection, considering that serious failures can occur in the main network, through a prototype that foresees problems in this network and anticipates it, presenting a solution so that the user does not notice connection failures. Considering such a device, it is intended to evaluate its impact on the well-being of the customer who acquires it, according to the connection needs of different groups. Therefore, exploratory research is described since the impact on the clients' well-being was not studied in previous analyses. For the design of this research, it is understood that a survey-type survey is indicated, as it is intended, through questionnaires with Likert-type scales and short open questions, to capture the different needs and reactions in different social groups, chosen according to the need for internet access. This work, however, analyzes a case study in a focus group, in a home office, from the perspective of the importance of a resilience device in computer networks as a promoter of the personal well-being of individuals participating in the research. At the end of this study, we intend to answer the following research question: "Does resilience in computer networks influence the well-being of individuals who use it?"
\end{abstract}

Keywords: Computer Engineering; Computer network; Psychological Well-Being; Network Resilience.

\section{RESUMO}

Dos personal computers e o seu acesso à internet em um lugar fixo, aos smartphones atuais com acesso à internet personalizado e em qualquer lugar, as mudanças comportamentais decorrentes dos avanços tecnológicos se acumulam diariamente. Com a pandemia de COVID-19 e a ampliação do home office, ensino domiciliar, telemedicina, dentre inúmeras outras atividades desenvolvidas remotamente como consequência do distanciamento social, a internet passa a figurar espaço singular em atividades em que

\footnotetext{
${ }^{1}$ Universidade Católica de Petrópolis.

${ }^{2}$ Colégio de Aplicação da Universidade Católica de Petrópolis

*E-mail: ana.carius@ucp.br
} 
antes não exercia tal papel. Diante desse cenário emergencial e histórico, o presente trabalho tem por objetivo avaliar o impacto social de uma solução de resiliência para redes computacionais, baseada na necessidade contínua de conexão da sociedade atual. O dispositivo em questão mantém a conexão com a internet, considerando que falhas graves podem ocorrer na rede principal, através de um protótipo que antevê problemas nesta rede e se antecipa, apresentando uma solução de forma que o usuário não perceba falhas de conexão. Considerando tal dispositivo, pretende-se avaliar o impacto deste no bem-estar do cliente que o adquire, de acordo com as necessidades de conexão de diferentes grupos. Portanto descrevese uma pesquisa de caráter exploratório, uma vez que o impacto para o bem-estar dos clientes não foi objeto de estudo em análises anteriores. Para o delineamento da presente pesquisa, entende-se que um levantamento do tipo survey é o indicado, uma vez que se pretende através de questionários com escalas do tipo Likert e questões abertas curtas, captar as diferentes necessidades e reações em diferentes grupos sociais, escolhidos de acordo com a necessidade de acesso à internet. Esse trabalho, no entanto, analisa um estudo de caso em um grupo focal, em home office, na perspectiva da importância de um dispositivo de resiliência em redes de computadores como promotor do bem-estar pessoal dos indivíduos participantes da pesquisa. Ao final deste estudo pretende-se responder a seguinte pergunta de pesquisa: "A resiliência em redes de computadores exerce influência no bem-estar dos indivíduos que dela usufruem?" Resumo no segundo idioma, com as mesmas regras e a mesma formatação do anterior.

Palavras-chave: Engenharia da Computação; Redes de Computadores; Bem-estar Psicológico; Resiliência em Redes.

\section{INTRODUCTION}

In the 1990s, access to the Internet started becoming popular, although the first computer networks were registered decades before. In fact, the transition from an analog world to a digital world has been taking place gradually since personal computers arrived in everyday activities, starting to figure in everyday life. As advances in the technological area were taking place and consequent improvements to computer networks became real, the internet came to figure as essential for several activities, rearranging the social fabric.

The COVID-19 pandemic evidenced significant advances regarding internet access and use. The inexorable need for social distancing to prevent the increase in infections due to the Sars-Cov-2 coronavirus has gained new meaning with the broad possibility of accessing the internet and constant use of it for various activities. It was, without a doubt, the first time in human history that educational institutions around the world were closed at the same time with the possibility of maintaining activities remotely mediated by different technologies. As in the example of the educational area, effects multiply in other areas: telemedicine, legal activities such as hearings, virtual personal trainer services, delivery services for numerous goods, all these services supported 
simultaneously by the network of networks, the internet (CARIUS, 2020a; RODRIGUES e CARIUS, 2020).

With the COVID-19 pandemic, the current society's dependence on cyberspace was observed, which was defined by Pierre Lévy (2010, p.94) as "the communication space opened by the worldwide interconnection of computers and memories of computers" enters the scene, in an upload movement (LEMOS, 2013) to this new environment. For Santaella (2003), cyberspace is the informational space of networks, made up of bits and bytes, of zeros and ones, so that from the interior of computers to screens, it reaches us in the form of known languages. Therefore, cyberspace is nothing but a metaphorical way of naming the internet, "the network that contains almost all networks", so to speak.

However, access to cyberspace is only possible thanks to the popularization of the internet. If the COVID-19 pandemic had occurred a decade ago, certainly many of the remote activities that occur due to distance would not be viable due to the lack of infrastructure. And it is about the network infrastructure advances, evidenced by the rise of optical fiber in the cabling of computer networks that this work occurs. Carius (2020b) discusses these new perspectives in her work.

Failures in computer networks occur due to adverse events, which can originate from periodic maintenance or resulting from natural accidents to catastrophic events such as floods, earthquakes, terrorist attacks or hurricanes. This project focuses on the dichotomy between the increased need for internet access and the lack of internet supply for households, which is increasingly necessary due to the "network society", as Manuel Castells (2019) named it.

For Sterbenz et al. (2010), the global internet can be described as one of the critical infrastructures on which our lives and prosperity depend, along with transport, infrastructure, power generation and distribution network. Fixes of failures in the computer nof a resilience model for computer networks, based on residential internet access from two different provietwork are the object of research in this project.

This paper presents a case study regarding the users. The following principles of resilience for the prototype are guided, according to Ungar (2018):

Principle 1 - Resilience occurs in a context of adversity

Principle 2 - Resilience is a process 
Principle 3 - There are exchanges between systems when a system experiences resilience

Principle 4 - A system of resilience is open, dynamic and complex

Principle 5 - A system of resilience promotes connectivity.

Principle 6 - A system of resilience demonstrates experimentation and learning

Principle 7 - A system of resilience includes diversity, redundancy and participation

It is intended to analyze the cost/benefit ratio for the adoption of this method of access to the residential internet for users/consumers who will use the prototype, considering the different needs of different groups of customers. At the end of this work, we intend to answer the following research question: "Does resilience in computer networks influence the well-being of individuals who use it?"

\section{LITERATURE REVIEW}

The resilience theme has gained greater importance in the academic world in recent years, being applied in different areas. The work by Hosseini et al. (2015) presents a rich survey of resilience, considering the different areas to which the term can be applied. The authors highlight a greater representation of the term in psychology, accompanied by the areas of sociology and anthropology, with the same relevance in environmental sciences and ecology. There is less relevance, according to the same authors, for the use of the term resilience in the field of engineering and computer science. The designation for the term network resilience, the subject of this work, is even smaller.

Considering the importance of the topic in question, a literature review was carried out to observe how the theme of resilience in networks is treated from an academic point of view. It was intended, first, to look for works that relate the device of resilience in networks with the user's well-being, under the psychological aspect. Searches were performed in Google Scholar, CAPES theses and dissertations database, and in CAPES periodicals using the key terms "resilience", "networks" and "psychology", both in Portuguese and in English. Despite the searches in three different databases, no papers with the same objective and purpose of this research were found.

In view of this fact, a literature review was started on the Google Scholar platform, for works that try to define the term resilience, regardless of the area. The key 
terms used were "resilience definition" or simply "resilience". In this second moment, works in English were prioritized. At first, eight works were listed which defined resilience from the perspective of one or more scientific areas. Among these eight works, in Table 1, definitions in different areas of knowledge were highlighted, in four works.

Table 1 - Different definitions for the term resilience, depending on the scientific area.

\begin{tabular}{|c|c|c|c|c|}
\hline Title & Authors & Source & Resilience definition & Application area \\
\hline $\begin{array}{l}\text { Resilience: } \\
\text { Theory and } \\
\text { Applications }\end{array}$ & $\begin{array}{l}\text { L. Carlson, G. } \\
\text { Bassett, W. } \\
\text { Buehring, M. } \\
\text { Collins, S. } \\
\text { Folga, B. } \\
\text { Haffenden, F. } \\
\text { Petit, J. Phillips, } \\
\text { D. Verner, R. } \\
\text { Whitfield }\end{array}$ & $\begin{array}{l}\text { Argonne } \\
\text { National } \\
\text { Laboratory }\end{array}$ & $\begin{array}{l}\text { "The } \\
\text { ability of an entity - } \\
\text { asset, organization, } \\
\text { community, region - to } \\
\text { anticipate, resist, absorb, } \\
\text { respond to, adapt to, and } \\
\text { recover from a } \\
\text { disturbance." }\end{array}$ & $\begin{array}{l}\text { Economic } \\
\text { Civil Society } \\
\text { Critical } \\
\text { Infrastructure } \\
\text { Supply } \\
\text { Chain/Dependencie } \\
\text { s } \\
\text { Governance }\end{array}$ \\
\hline $\begin{array}{l}\text { A metric and } \\
\text { frameworks } \\
\text { for resilience } \\
\text { analysis of } \\
\text { engineered } \\
\text { and } \\
\text { infrastructur } \\
\text { e systems }\end{array}$ & $\begin{array}{l}\text { Royce Francis } \\
\text { Behailu Bekera }\end{array}$ & $\begin{array}{l}\text { Reliability } \\
\text { Engineering } \\
\text { and System } \\
\text { Safety }\end{array}$ & $\begin{array}{l}\text { "Infrastructure resilience is } \\
\text { the ability to reduce the } \\
\text { magnitude and/or duration } \\
\text { of disruptive events. } \\
\text { The effectiveness of a } \\
\text { resilient infrastructure or } \\
\text { enterprise depends upon its } \\
\text { ability to anticipate, } \\
\text { absorb, } \\
\text { adapt to, and/or rapidly } \\
\text { recover from a potentially } \\
\text { disruptive event." }\end{array}$ & $\begin{array}{l}\text { Infrastructure } \\
\text { systems }\end{array}$ \\
\hline $\begin{array}{l}\text { A metric and } \\
\text { frameworks } \\
\text { for resilience } \\
\text { analysis of } \\
\text { engineered } \\
\text { and } \\
\text { infrastructur } \\
\text { e systems }\end{array}$ & $\begin{array}{l}\text { Royce Francis } \\
\text { Behailu Bekera }\end{array}$ & $\begin{array}{l}\text { Reliability } \\
\text { Engineering } \\
\text { and System } \\
\text { Safety }\end{array}$ & $\begin{array}{l}\text { "Resilience refers to the } \\
\text { ability of an organization } \\
\text { to anticipate, circumvent } \\
\text { threats to its existence \& } \\
\text { primary goals } \\
\text { and rapidly recover." }\end{array}$ & $\begin{array}{l}\text { Safety Management } \\
\text { system }\end{array}$ \\
\hline $\begin{array}{l}\text { A metric and } \\
\text { frameworks } \\
\text { for resilience }\end{array}$ & $\begin{array}{l}\text { Royce Francis } \\
\text { Behailu Bekera }\end{array}$ & $\begin{array}{l}\text { Reliability } \\
\text { Engineering } \\
\text { and System }\end{array}$ & $\begin{array}{l}\text { "Resilience is the ability to } \\
\text { recognize \& adapt to } \\
\text { handle unanticipated }\end{array}$ & $\begin{array}{l}\text { Organizational } \\
\text { system }\end{array}$ \\
\hline
\end{tabular}




\begin{tabular}{|c|c|c|c|c|}
\hline $\begin{array}{l}\text { analysis of } \\
\text { engineered } \\
\text { and } \\
\text { infrastructur } \\
\text { e systems }\end{array}$ & & Safety & $\begin{array}{l}\text { perturbations that call into } \\
\text { question the } \\
\text { model of competence, and } \\
\text { demand a shift of process, } \\
\text { strategies and } \\
\text { coordination." }\end{array}$ & \\
\hline $\begin{array}{l}\text { A metric and } \\
\text { frameworks } \\
\text { for resilience } \\
\text { analysis of } \\
\text { engineered } \\
\text { and } \\
\text { infrastructur } \\
\text { e systems }\end{array}$ & $\begin{array}{l}\text { Royce Francis } \\
\text { Behailu Bekera }\end{array}$ & $\begin{array}{l}\text { Reliability } \\
\text { Engineering } \\
\text { and System } \\
\text { Safety }\end{array}$ & $\begin{array}{l}\text { "Resilience is the ability of } \\
\text { the system to maintain its } \\
\text { identity in the face of } \\
\text { change and external shocks } \\
\& \\
\text { disturbances. Component } \\
\text { of the system, the } \\
\text { relationship among these } \\
\text { components and the ability } \\
\text { of these } \\
\text { components \& } \\
\text { relationships to maintain } \\
\text { themselves constitutes } \\
\text { system identity." }\end{array}$ & $\begin{array}{l}\text { Social-ecological } \\
\text { system }\end{array}$ \\
\hline $\begin{array}{l}\text { A metric and } \\
\text { frameworks } \\
\text { for resilience } \\
\text { analysis of } \\
\text { engineered } \\
\text { and } \\
\text { infrastructur } \\
\text { e systems }\end{array}$ & $\begin{array}{l}\text { Royce Francis } \\
\text { Behailu Bekera }\end{array}$ & $\begin{array}{l}\text { Reliability } \\
\text { Engineering } \\
\text { and System } \\
\text { Safety }\end{array}$ & $\begin{array}{l}\text { "Economic resilience } \\
\text { refers to the inherent \& } \\
\text { adaptive responses to } \\
\text { hazards that enable } \\
\text { individuals and } \\
\text { communities to avoid } \\
\text { some potential losses. It } \\
\text { can take place at the level } \\
\text { of the firm, household, } \\
\text { market, or } \\
\text { macro economy. In } \\
\text { contrast to the pre-event } \\
\text { character of mitigation, } \\
\text { economic resilience } \\
\text { emphasizes ingenuity } \\
\text { and resourcefulness } \\
\text { applied during and after } \\
\text { the event." }\end{array}$ & Economic Systems \\
\hline $\begin{array}{l}\text { A metric and } \\
\text { frameworks } \\
\text { for resilience } \\
\text { analysis of } \\
\text { engineered } \\
\text { and }\end{array}$ & $\begin{array}{l}\text { Royce Francis } \\
\text { Behailu Bekera }\end{array}$ & $\begin{array}{l}\text { Reliability } \\
\text { Engineering } \\
\text { and System } \\
\text { Safety }\end{array}$ & $\begin{array}{l}\text { "Resilience is the ability of } \\
\text { groups or communities to } \\
\text { cope with external stresses } \\
\text { and disturbances as a result } \\
\text { of } \\
\text { social, political, and }\end{array}$ & Social System \\
\hline
\end{tabular}




\begin{tabular}{|c|c|c|c|c|}
\hline $\begin{array}{l}\text { infrastructur } \\
\text { e systems }\end{array}$ & & & environmental change." & \\
\hline $\begin{array}{l}\text { Resilience: } \\
\text { a literature } \\
\text { review }\end{array}$ & $\begin{array}{l}\text { Patrick Martin- } \\
\text { Breen } \\
\text { J. Marty } \\
\text { Anderies }\end{array}$ & $\begin{array}{l}\text { Institute of } \\
\text { Development } \\
\text { Studies }\end{array}$ & $\begin{array}{l}\text { "Something is } \\
\text { resilient if it can resist } \\
\text { external forces, shocks, } \\
\text { and disturbances and can } \\
\text { quickly return to its normal } \\
\text { state." }\end{array}$ & Engineering \\
\hline $\begin{array}{l}\text { Resilience: } \\
\text { a literatura } \\
\text { review }\end{array}$ & $\begin{array}{l}\text { Patrick Martin- } \\
\text { Breen } \\
\text { J. Marty } \\
\text { Anderies }\end{array}$ & $\begin{array}{l}\text { Institute of } \\
\text { Development } \\
\text { Studies }\end{array}$ & $\begin{array}{l}\text { "Resilience is then defined } \\
\text { as a ongoing process of } \\
\text { continual positive adaptive } \\
\text { changes to adversity, } \\
\text { which } \\
\text { changes enable future } \\
\text { positive adaptive changes." }\end{array}$ & Psychology \\
\hline $\begin{array}{l}\text { Network } \\
\text { Resilience: } \\
\text { A Systematic } \\
\text { Approach }\end{array}$ & $\begin{array}{l}\text { Paul Smith } \\
\text { David Hutchison } \\
\text { James P. G. } \\
\text { Sterbenz } \\
\text { Marcus Schöller } \\
\text { Ali Fessi } \\
\text { Merkouris } \\
\text { Karaliopoulos } \\
\text { Chidung Lac } \\
\text { Bernhard } \\
\text { Plattner }\end{array}$ & $\begin{array}{l}\text { IEEE } \\
\text { Comunicatio } \\
\text { ns Magazine }\end{array}$ & $\begin{array}{l}\text { "Resilience is the ability of } \\
\text { a network to defend } \\
\text { against and maintain an } \\
\text { acceptable level of service } \\
\text { in the presence of such } \\
\text { challenges, is viewed } \\
\text { today, more than over } \\
\text { before, as a major } \\
\text { requirement and design." }\end{array}$ & Network Resilience \\
\hline
\end{tabular}

Source: Carius et al. (2021)

From the information listed in Table 1, it is observed that the term resilience can designate concepts related to infrastructure systems, economics, social systems, organizational systems, security systems, psychology, ecological-social system, engineering and, finally, resilience in the computer network environment.

It appears from the readings carried out that the term resilience has its origin identified with the exact sciences. According to Brandão et al. (2011)

Researchers who speak Latin languages (including Brazilians) point out that
the term/concept "resilience" would have been taken from the exact sciences,
more specifically from the field of resistance of materials, while pioneering
researchers on the subject, the British and North Americans, said nothing about
the origin. (BRANDÃO et al., 2011, p.264)

The work of Martin-Breen and Anderies (2011), when referring to the definition of resilience related to engineering, corroborates the similarity to materials science, according to Brandão et al. (2011) affirms. 
Considering the works selected for this literature review, a common character in the definitions of resilience can be observed. Briefly, resilience refers to a behavior assumed from a rupture or trauma (which can be psychological or a technical failure, considering computer networks, for example), in which the person or the system acquires repositioning capacity in the face of of rupture and, after a period of recovery, it returns to the original position, which is not always identical to the position it had before the rupture event, and this position may be lower, equal to or higher than the original configuration.

It is about this concept of trauma or adverse event, causing a break with the need for recovery time to return to the original configuration, that's where this work is situated. From the point of view of computer networks, it is possible to design a device for resilience, to minimize the effects of a possible failure, avoiding situations of personal discomfort when the internet is extremely necessary. The impact of the action of this resilience device on computer networks for different groups of users is then discussed.

\section{RESEARCH METHODOLOGY}

Since the research theme is relevant and little explored with regard to the computer network, considering the literature review described in section 2, the research began on a qualitative and quantitative basis.

At first, a group of volunteer participants was selected to develop data collection through a questionnaire. According to Mattar and Ramos (2021, p.215), "questionnaires are used mainly in research with quantitative approaches, because they are mainly composed of objective questions, which require analyzes based on descriptive and/or inferential statistics." As questions on the seven-point Likert scale were used in this questionnaire, a qualitative and quantitative data collection instrument is characterized: qualitative because it is understood that the sensitivity scale submitted to the participant offers a subjective view of the topic.; quantitative because, by adapting the responses to the Likert scale, it is possible to obtain measures of central tendency and measures of dispersion, making a quantitative reading of the data presented, in addition to being possible to build graphs and verify correlations between the data presented.

Therefore, data collection was carried out in a group of 210 participants, most from the area of computer networks, who are used to evaluating the impact of internet 
failure or interruption to perform their work activities. Thus, it was intended to define paths for a survey-type survey, in progress, which will consider other areas and the need for each one of them in relation to a system of computer networks protected from failures.

\section{RESULTS AND DISCUSSION}

It was presented to the research participants, through the questionnaire, 10 scenarios in which these people would place themselves and there was an internet failure (with no return forecast), such as online classes, job interviews and work meetings, for example. They were asked how they would feel on a scale of 1 to 7 , where 1 would be very dissatisfied and 7 would be very satisfied. Figure 1 shows the percentage of dissatisfaction with the internet failure from a perspective without a resilience device. Note that total dissatisfaction is around $54.81 \%$.

Figure 1 - Dissatisfaction in the scenario with lack of resilience

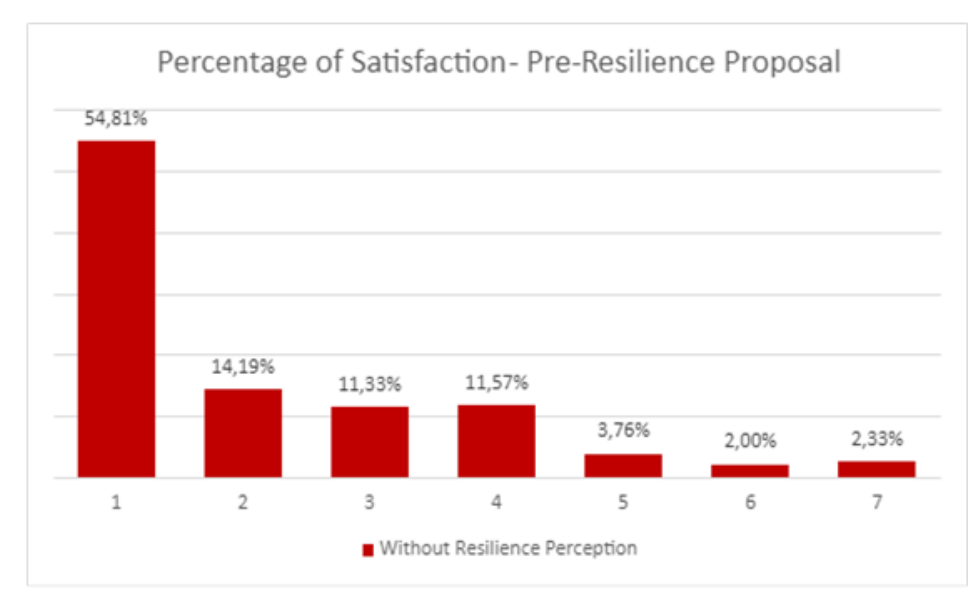

Source: Carius et al. (2021)

Then, it was explained how a resilient solution tolerant to this type of failure would be. So, the research participants were asked to put themselves again in the 10 proposed situations, but this time knowing that they would have this resilient solution. Figure 2 presents the perspective of satisfaction, given the new scenario. There is a new perspective of satisfaction, with $50.71 \%$ of participants fully satisfied with the proposal. Figure 3 presents the two consolidated results.

Figure 2 - Satisfaction in the presence of resilience 


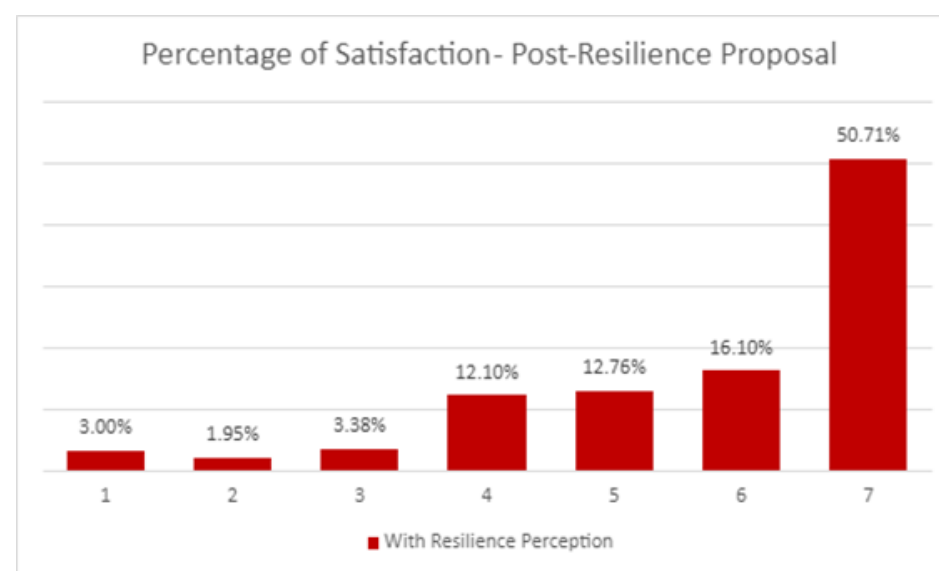

Source: Carius et al. (2021)

Figure 3 - Relationship between satisfaction and dissatisfaction through the adoption of the device of resilience in networks

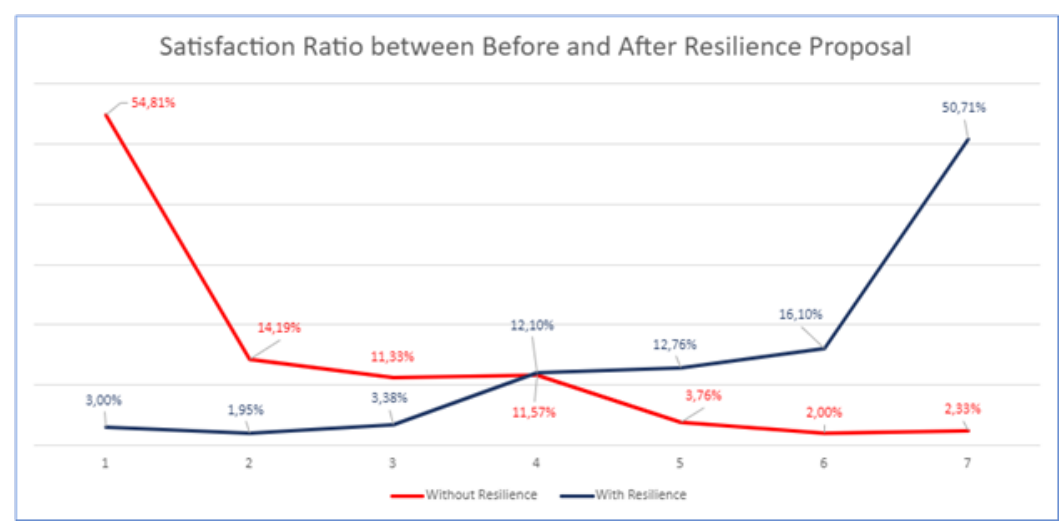

Source: Carius et al. (2021)

\section{CONCLUSION}

The present work discussed the impact, from the point of view of social wellbeing, of the adoption of a device of resilience in computer networks. Considering the pandemic and post-pandemic scenario, in which the need for the internet is essential to access various social aspects, including health, education, commerce and leisure, the motivation for the adoption of a device that provides internet without interruption is evident.

The field research present in this work sought to assess the impact on the participants' well-being regarding the existence or not of a failure in the participants' internet device. From the results obtained, it was observed a considerable importance of not falling from the internet as a guarantee of the user's well-being, according to the 
scenarios presented. Therefore, it is concluded that the adoption of resilience devices in internet networks can positively affect the users' well-being, improving their psychological and social aspects.

\section{REFERENCES}

BRANDÃO, J. M., MAHFOUD, M., GIANORDOLI-NASCIMENTO, I.F. A construção do conceito de resiliência em psicologia: discutindo as origens. Paideia, v.21, n.49, p. 263-271, 2011.

CARIUS, A. C. Network Education and Blended Learning: Cyber University concept and Higher Education post COVID-19 pandemic. Research, Society and Development, v.9, n.10, p.1-16, 2020a.

CARIUS, A.C. Teaching Practices in Mathematics during COVID-19 pandemic: Challenges for Technological Inclusion in a Rural Brazilian School. American Scientific Research Journal for engineering, technology and sciences, v.72, n.1, p.35-43, 2020 b.

CARLSON, L., BASSETT, G., BUEHRING, W., COLLINS, M., FOLGA, S., HAFFENDEN, B., PETIT, F., PHILLIPS, J., VERNER, D., WHITFIELD, R. Resilience: Theory and Applications. Decision and Information Sciences Division, Argonne National Laboratory, 2012.

CASTELlS, M. A sociedade em rede. 20a edição. Paz e Terra, 2019.

FRANCIS, R., BEKERA, B. A metric and frameworks for resilience analysis of engineered and infrastructure systems. Reliability Engineering \& System Safety, v.121, p.90-103, 2014.

HOSSEINE, S., BARKER, K., RAMIREZ-MARQUEZ, J. E. A review of definitions and measures of system resilience. Reliability Engineering and System Safety, v.145, p.47-61, 2016.

LEMOS, A. A comunicação das coisas: teoria ator-rede e cibercultura. Annablume, 2013.

LÉVY, P. Cibercultura. $3^{\text {a }}$ edição. Editora 34, 2010.

MARTIN-BREEN, P., ANDERIES, J. M. Resilience: a literature review. The Future of Philanthropy and Development in the Pursuit of Human Wellbeing, Bellagio Initiative, 2011.

MATTAR, J., RAMOS, D. K. Metodologia da pesquisa em educação. Edições 70, 2021.

RODRIGUES, P.H.E., CARIUS, A.C. The Implementation of Emergency Remote Education in Brazilian Educational Systems. American Scientific Research Journal for Engineering, Technology, and Science, v.74, n.2, p.181-194, 2020.

SANTAELLA, L. Da cultura das mídias à cibercultura: o advento do pós-humano. Revista FAMECOS, v.10, n.22., p.23-32, 2003. 
SMITH, P., HUTCHISON, D., STERBENZ, J. P. G., SCHÖLLER, M., FESSI, A., KARALIOPOULOS, M., LAC, C., PLATTNER, B. Network Resilience: a Systematic Approach. Topics in Network and Service Management: IEEE Communication Magazine, v.11, p.88-97, 2011.

STERBENZ, J.P.G., HUTCHISON, D., ÇETINKAYAe, E. K., JABBAR, A., ROHRER, J. P., SCHÖLLER, M., SMITH, P. Resilience and survivability in communication networks: Strategies, principles, and survey of disciplines. Computer Networks, v.54, p.1245-1265, 2010.

UNGAR, M. Systemic resilience: principles and processes for a science of change in contexts of adversity. Ecology and Society, v.23, n.4, p.34, 2018.

Recebido em: 10/10/2021

Aprovado em: 10/11/2021

Publicado em: 18/11/2021 